\title{
Promote cheaper generic drugs to patients - and help contain medical inflation
}

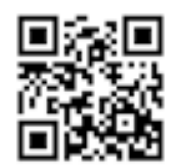

The country's top medical scheme administrator, Discovery Health, calculates that far greater use of cheaper, good-quality generic drugs will drive down healthcare inflation, saving as much as R1.5 billion per annum for medical scheme members while a major hospital group has begun promoting use of these medicines through its hospital pharmacies.

This emerged at a pioneering daylong medicine summit convened by the administration and managed healthcare giant in Sandton, Johannesburg, on 15 May this year and attended by representatives of the local and international pharmaceutical industry, private hospital executives and government drug regulation advisors. Setting the scene for the summit, Discovery Health CEO Jonny Broomberg challenged his predominantly drug-company audience to enter risk-sharing and 'payment for value' agreements, plus volume-based pricing, appealing to them to work with the National Department of Health $(\mathrm{NDoH})$ to keep the cost of medicines affordable in the private sector.

'We often hear from you that the Department of Health is not supportive of this risk-sharing agreement - my theory is that you guys are not sufficiently motivated to push this approach. We need to work harder with the $\mathrm{NDoH}$ to tackle inefficiencies and perversities throughout the medicine supply chain. It doesn't make sense that many products, especially some generics, maintain such high prices and yet still have the largest market share. This defies market logic', he said. Relative to global benchmarks on drug pricing, South Africa (SA)'s private sector pricing was high and rigid, and he predicted that 'the time of arbitrary high pricing because you can' was coming to an end.

\section{Market ignoring competitively priced drugs - Broomberg}

Broomberg said one problem was that the gap between leading generic products and leading 'original' brand-name products was far narrower than in most international environments, with many generics entering the SA market at a $20-30 \%$ price differential to the originator product, compared with up to $90 \%$ in developed countries, including the USA and countries in Europe. 'The second problem is that our market is currently failing to take advantage of competitively priced generics. There are generics very competitively priced in most chronic categories, but somehow our members end up paying for much higher-priced equivalent 
generics because of perversities in the supply chain. The most expensive generics dominate the market, and money moving between the manufacturers and dispensers was leading to the expensive products being dispensed when better-priced alternatives are available, which Broomberg described as 'unacceptable'. He said the current Market Inquiry into Private Healthcare under the auspices of the Competition Commission was likely to investigate this. 'It's a classic example of market failure ... This kind of approach is damaging the medical scheme environment, and none of us can afford to take the short-term view. We've got to think about what happens when people drop out of medical aids because they can't afford medicines and other high-cost interventions.

Broomberg said that the rapid growth in the consumption of chronic medication (a windfall for the pharmaceutical companies, although not their fault) needed price adjustments and transparency to allow medical schemes to 'ensure that we can continue to support patients dealing with these diseases'. He revealed that Discovery Health's MedXpress offering of free home and work delivery of drugs was being expanded to include the delivery of specialised high-cost medicines direct to doctors' practices, with an initial focus on the oncology sector. The company was also combining all its units dealing with medicines into a single entity, enabling pharmaceutical and other companies to interact with Discovery Health through a highly efficient single point of contact.

\section{Boom in chronic medicine use}

Discovery Health's Head of Risk Management Strategy, Ismail Rasool, highlighted the 'enormous cost-containing potential' if patients started to purchase the lowestpriced generic equivalents currently on the market, putting the saving for the medical schemes that Discovery Health administers at approximately R500 million. Extrapolating this to the other major medical schemes would generate savings of up to R1.5 billion per annum just by shifting current dispensing towards lower-cost rather than the highestcost generics. This alone could reduce premiums by $1-2 \%$ per year. Putting figures to Broomberg's assertion on the rapid growth of chronic medication consumption, he said that in 2003, $10 \%$ of Discovery Health Medical Scheme members had a chronic condition at an average age of 32. Last year (one decade later) this had increased to $20 \%$ at the same age. By the time members were 65 , three out of five had a chronic condition, all underlying trends that he described as 'very worrying. In the year 2000, the scheme had 15/10 000 lives claiming more than half a million rands - by 2014, this number had gone up five-fold to $79 / 10000$, even after adjusting for inflation. 'So without younger, healthier lives coming into the system, there's immense pressure on schemes to ensure cost-effective medicines are prescribed and dispensed.

\section{'It doesn't make sense that} many products, especially some generics, maintain such high prices and yet still have the largest market share. This defies market logic.'

'The scheme's total medicine expenditure (including hospital oncology) has gone up by $92 \%$ from R4 billion in 2008, Broomberg added. Among the diseases of lifestyle driving chronic medicines consumption were hypertension, diabetes and hyperlipidaemia. HIV was growing, but at nowhere near the same rate, with Discovery Health Medical Scheme now funding 38000 members for HIV-associated conditions. A particular concern is the impact of expensive new drugs for conditions such as cancer, rheumatoid arthritis and multiple sclerosis. These, together with a sub-set of similar novelty drugs, are predicted to increase in cost to R2.3 billion by 2020 , from almost nothing in 2008. 'We need to look at risk sharing and alternative reimbursement models to allow medical schemes to manage this cost explosion in a sustainable way.'

\section{SA's drug spend disproportionate to other similar countries}

Discovery Health Medical Scheme data suggest that SA's private healthcare system spends disproportionately more on medicines, relative to total healthcare expenditure, than in the top ten comparative countries featured in a health systems performance study by the monitor group.

While the use of generics in hospitals had improved, there was 'room for more', Broomberg said. Further illustrating Broomberg's concern about the high price point at which generics were being used, Rasool said that the average price difference (brand to generic) in the lowest price band was $60 \%$. The same difference when comparing the mid-range price band was $45 \%$, while the top-priced comparison revealed a 39\% difference. During open discussion, Paul Anley, CEO of Pharma Dynamics, one of SA's foremost distributors of generic drugs, said that the reason for the large percentage price gap between brand name and generic drugs in the lowest price range was because they were not being actively marketed. 'You have to be careful of just putting emphasis on price - because if you don't tell anybody, you don't get the switch!' he warned.

Anley also said inefficiencies in SA legislation meant that patent 'evergreening' on original drugs (taking out multiple patents expiring at later and later dates to protect monopolies) worked to the great advantage of many drug companies. 'They're often challenged in foreign courts where the patents are quickly set aside. In SA, delays in a hearing for a revocation of a patent can take up to four years. We also don't have dedicated patent judges and a skills base.' Very often valid patents 'on the books' in SA had long been overturned in most other countries where generics then traded more freely. Anley said his calculations were that if one took the entire (private) branded drug market of R28 billion in SA and divided it by the number of packs sold, you got an average branded price of R219. A similar calculation in the generic market disclosed a figure of R73 - a differential of R146, or $72 \%$ across the board. 'That is the impact that generics are making in pharma,' he said. Interviewed during a break, Anley said the total pharmaceutical market in SA stood at about R34 billion (R28 private sector and R5.5 billion state). He emphasised that when more expensive generics entered and gained traction in the market, sales volumes soon reached three times what the original brand was two or three years earlier. Anley cautioned against driving generic prices 'down to the point where nobody uses them', and said there was an inbuilt 'catch 22': low prices often meant that generic drug companies avoided spending money marketing these products - 'that's why they don't move, not just because of price. Rasool said Discovery Health's data confirmed the initial market traction of generics. 'But what we're saying is that when people choose generics, it seems the most expensive ones are being used rather than the less expensive ones. This raises questions about the incentives being used to promote these more expensive generics, he said.

\section{Support smaller drug companies selling at more competitive prices - MediClinic}

Anelia Bezuidenhout of MediClinic said that last year her hospital group put all their pharmaceutical products into groups with prior rankings in price bands before approaching their individual hospitals and 
requesting them to 'move to number one the better-priced products'. 'In the beginning there were many stock-outs on the smaller drug companies, but slowly they increased their supplies and expanded their services to help us reach our goal. Yes, it's true that your smaller company doesn't deliver the required service, but over time they will!' she stressed.

In his opening address Broomberg said that with medical inflation running at $10.3 \%$ in SA (three percentage points above the general consumer price index), $6 \%$ was a result of changes in the price of goods and services - but the other $4.3 \%$ was due to more goods and services being consumed every year by the average medical scheme member. Discovery Health Medical Scheme currently spends R5 billion on 'outof-hospital' medications (R1.3 billion on 'in-hospital' medications) with $15 \%$ of all claims in medicine, while 486000 of the scheme's 2.7 million members are registered for one or more chronic conditions.

\section{Chris Bateman}

chrisb@hmpg.co.za

S Afr Med J 2014;104(9):598-600.

DOI:10.7196/SAMJ.8750 